\title{
Mixotrophic algal-protein production and techno-economic analysis based in
}

\section{medium formulation}

\author{
Produção mixotrófica de proteína de algas e análise tecno-econômica baseadla na formulação do \\ meio de cultivo \\ Producción mixotrofica de proteína de algas y análisis técnico y económico basado en la \\ formulación del medio de cultivo
}

Received: 03/23/2021 | Reviewed: 04/09/2021 | Accept: 04/12/2021 | Published: 04/22/2021

\author{
Paula Scanavez Ferreira \\ ORCID: https://orcid.org/0000-0002-7090-2902 \\ Federal University of Uberlandia, Brazil \\ E-mail: paulascanavez1@gmail.com \\ Gabriela Aparecida Santos \\ ORCID: https://orcid.org/0000-0002-9111-493X \\ Federal University of Uberlandia, Brazil \\ E-mail: gabi.a.santos@outlook.com \\ Isadora Torres de Souza \\ ORCID: https://orcid.org/0000-0002-6382-6673 \\ Federal University of Uberlandia, Brazil \\ E-mail: iisadora.torres@gmail.com \\ Sérgio Mauro da Silva Neiro \\ ORCID: https://orcid.org/0000-0002-1920-6573 \\ Federal University of Uberlandia, Brazil \\ E-mail: srgneiro@ufu.br \\ Vicelma Luiz Cardoso \\ ORCID: https://orcid.org/0000-0002-8278-6988 \\ Federal University of Uberlandia, Brazil \\ E-mail: vicelma@ufu.br \\ Fabiana Regina Xavier Batista \\ ORCID: https://orcid.org/0000-0001-6314-0367 \\ Federal University of Uberlandia, Brazil \\ E-mail: frxbatista@ufu.br
}

\begin{abstract}
The use of Spirulina platensis for human consumption, due to the wide benefits gained as higher protein content, low calories, and high nutritional value, grows every year. Besides, several studies have tested alternative culture media to increase the level of biomass density and protein content, besides reducing the costs of production. Glucose (GLC) is a known component used to provide cell growth because it increases the carbon content of microalgae; however, there is no record of the use of the fetal bovine serum (FBS), a supplement widely used for animal cell culture. The current work aimed to analyze the isolated and combined effect of glucose and FBS, synergism, and antagonism on the $S$. platensis culture development. A techno-economic analysis was also proposed. The effect between GLC and FBS increased the biomass density $(0.44 \mathrm{~g} / \mathrm{L})$ and chlorophyll content $\left(0.72 \mathrm{mg} / \mathrm{m}^{3}\right)$. However, the condition with higher protein concentration seemed to be the one supplemented only with FBS. The result may show that protein production does not follow the same rule as biomass density. Further, the cost-benefit analysis showed gains of a projected venture with the discounted payback period (DPBP) of three years.
\end{abstract}

Keywords: Spirulina platensis; Fetal bovine serum; Glucose; Total protein; Cost performance.

\section{Resumo}

O uso da Spirulina platensis para consumo humano, devido aos amplos benefícios obtidos como maior teor de proteínas, baixas calorias e alto valor nutricional, cresce a cada ano. Além disso, diversos estudos testaram meios de cultura alternativos para aumentar o nível de densidade da biomassa e o teor de proteína, além de reduzir os custos de produção. A glicose (GLC) é um componente conhecido usado para fornecer crescimento celular porque aumenta o conteúdo de carbono das microalgas; entretanto, não há registro do uso do soro fetal bovino (SFB), suplemento amplamente utilizado para cultura de células animais. O presente trabalho teve como objetivo analisar o efeito isolado e combinado da glicose e SFB, sinergismo e antagonismo no desenvolvimento da cultura de S. platensis. Uma análise técnico-econômica também foi proposta. O efeito entre GLC e SFB aumentou a densidade da biomassa $(0,44 \mathrm{~g} / \mathrm{L})$ e o 
conteúdo de clorofila $\left(0,72 \mathrm{mg} / \mathrm{m}^{3}\right)$. No entanto, a condição com maior concentração de proteína parecia ser aquela suplementada apenas com SFB. O resultado mostrar que a produção de proteína não segue a mesma regra da densidade de biomassa. Além disso, a análise de custo-benefício mostrou ganhos de um empreendimento projetado com o DPBP de três anos.

Palavras-chave: Spirulina platensis; Soro fetal bovino; Glicose; Proteina total; Análise de custo.

\section{Resumen}

El uso de Spirulina platensis para consumo humano, debido a los amplios beneficios que se obtienen como un mayor contenido en proteínas, bajas calorías y alto valor nutricional, crece cada año. Además, varios estudios han probado medios de cultivo alternativos para aumentar el nivel de densidad de biomasa y contenido de proteínas, además de reducir los costos de producción. La glucosa (GLC) es un componente conocido que se utiliza para proporcionar crecimiento celular porque aumenta el contenido de carbono de las microalgas; sin embargo, no existe constancia del uso de suero fetal bovino (SFB), un suplemento ampliamente utilizado para el cultivo de células animales. El presente trabajo tuvo como objetivo analizar el efecto aislado y combinado de glucosa y SFB, sinergismo y antagonismo en el desarrollo del cultivo de $S$. platensis. También se propuso un análisis técnico-económico. El efecto entre GLC y SFB aumentó la densidad de biomasa $(0,44 \mathrm{~g} / \mathrm{L})$ y el contenido de clorofila $\left(0,72 \mathrm{mg} / \mathrm{m}^{3}\right)$. Sin embargo, la condición con la concentración de proteína más alta pareció ser la suplementada con SFB solo. El resultado muestra que la producción de proteínas no sigue la misma regla que la densidad de biomasa. Además, el análisis de costo-beneficio mostró ganancias de un proyecto diseñado con el DPBP de tres años.

Palabras clave: Spirulina platensis; Suero bovino fetal; Glucosa. Proteina total; Análisis de costos.

\section{Introduction}

Opting for healthier eating habits, more nutritious foods, and reducing food-related problems such as protein insufficiency are major concerns that involve human nutrition. In the last decade, there has been a growing increase in the demand for new sources of protein besides the conventional ones, such as meat. Legumes, cereals, seeds, and also different types of microalgae have gained more space in people's daily meals. These factors are some of the reasons why microalgae cultivation has increased over the years, since some species can store high protein contents, such as Spirulina platensis.

S. platensis is a unicellular microalga that belongs to the group of cyanobacteria, also known as blue-green algae (Tortora, 2017). Besides the high protein content (approximately $70 \%$ of its biomass), S. platensis is also a source of provitamin A, absorbable iron, vitamin B12, phenolic compounds, amino acids, phycocyanin, carotenoids, $\gamma$-Linolenic acid, and other essential fatty acids (Habib et al., 2008; Henrikson, 2009; Von Der Weid and Falquet, 2000). As cyanobacteria do not have cellulose in its cell walls, it can be easily digested, which makes the microalgae suitable for human and animal consumption and also marketable in the form of capsules and / or tablet (Borowitzka, 1999; Dillon and Dubacq, 1995). Although S. platensis has an important nutritional value, its benefits are not restricted only to human and animal feed. It also presents antioxidative, immunostimulatory, and antimicrobial activity, anti-cancer effect, and protective effect against heavy metal toxicity (Hosseini et al., 2013; Shelke and Wani, 2015; Dar et al., 2014).

Several alternative culture media have been tested to increase protein and pigment production of microalgal biomass. Industrial effluents, beet vinasse, or even the addition of urea as a nitrogen source are some examples of supplementation to improve the productivity of high value-added products (Coca et al., 2015; Rangel-Yagui et al., 2004; Suali and Sabartly, 2012).

Glucose is one of the most common carbon sources used in microalgal cultures, whether on a laboratory or industrial scale (Suali and Sabartly, 2012). FBS is a supplement commonly used in cell cultures of tissues and organs and has in its composition more than a thousand different components, such as hormones, vitamins, nucleosides, amino acids, proliferation factors, lipids, transport proteins (albumin, globin, transferrin), binding factors (fibronectin and laminin) and growth factors (Staines and Price 2013). According to the International Serum Industry Association (Isia, 2020), there is a wide range of applications for processed bovine serum, but the most important is in the pharmaceutical area where it is used in the research, manufacture of biopharmaceuticals and biotechnological techniques. Despite all these benefits, no evidence of FBS supplementation in cyanobacteria culture was found in previous investigations. Thus, this work aimed to evaluate the growth 
of S. platensis under different supplementations using glucose and FBS and analyze the performance of both components on the total protein content and biomass density. Finally, a cost analysis showed the feasibility of the strategy.

\section{Methodology}

\subsection{Spirulina platensis and inoculum maintenance}

Spirulina platensis cultures were held at the School of Chemical Engineering of the Federal University of Uberlandia. They were kept in an environmental growth chamber at a constant temperature $\left(25^{\circ} \mathrm{C}\right)$, under a light cycle (night/day) of $12 \mathrm{~h}$ at $30 \mu \mathrm{E} / \mathrm{m}^{2} \mathrm{~s}$ and static culture. Twice a month, aliquots of $250 \mathrm{~mL}$ of algal culture were transferred to $250 \mathrm{~mL}$ of freshly prepared and sterile W.C Guillard and Lorenzen medium (Guillard and Lorenzen, 1972) for culture maintenance. The initial pH was adjusted to $6.5(2 \mathrm{M} \mathrm{HCl})$.

\subsection{Photo-fermentation - preliminary analysis}

Initially, a preliminary photo-fermentation was carried out in four different formulations containing or not GLC (NEON, Brazil) and FBS (Cultilab, Brazil). Each formulation was inoculated with an initial S. platensis biomass density of $0.1 \mathrm{~g} / \mathrm{L}$. Variable responses such as biomass density, chlorophyll, and total protein contents were monitored. It was used $250 \mathrm{~mL}$ conic bioreactors $(130 \mathrm{~mL}$ working volume) with the same condition of illumination and temperature from the inoculum. The photo-fermentation conditions were (1) Control: S. platensis cultivated in Guillard's W.C medium; (2) S. platensis cultivated in Guillard's W.C medium supplemented with GLC (5.25g/L); (3) S. platensis cultivated in Guillard's W.C medium supplemented with FBS (2.75\% v/v) and (4) S. platensis cultivated in Guillard's W.C medium supplemented with GLC (5.25g/L) and FBS $(2.75 \% \mathrm{v} / \mathrm{v})$, in which was tested the synergistic or antagonistic effects between both supplementations. All experiments were performed in replicates and these four formulations were used as the basis for the values defined at the central point of the Factorial Design informed below. Also, the initial chlorophyll content was $0.23 \mathrm{mg} / \mathrm{m}^{3}$.

\subsection{Photo-fermentation - factorial design}

In the second step of the study, the effects of GLC (from 1.44 to $11.94 \mathrm{~g} / \mathrm{L}$ ) and FBS (from 0.42 to $5.89 \% \mathrm{v} / \mathrm{v}$ ) were analyzed employing a star-expanded $2^{2}$ factorial design, in a total of 12 experiments. Also, there was a control (S. platensis in WC medium). Response variables were biomass density and total protein content. When required, the statistical effects of the independent variables on the response variables were calculated using the software Statistica ${ }^{\circledR 7.0 ~ s o f t w a r e . ~ E x p e r i m e n t s ~ w e r e ~}$ carried out with the same operating conditions of the preliminary photo-fermentation and also performed in replicates (6). However, it took only six days, instead of ten.

\subsection{Analytical methodology}

The biomass density $(\mathrm{g} / \mathrm{L})$ was determined by measuring the optical density $(570 \mathrm{~nm})$. For that, it was used the gravimetric method (Clesceri et al., 1998). A-chlorophyll $\left(\mathrm{mg} / \mathrm{m}^{3}\right)$ content was determined by the method of Jeffrey and Humphrey (1975) modified by Mohsenpour et al. (2012). To analyze the protein content, the Lowry method was employed (Lowry et al., 1951). Two calibration curves were prepared using Bovine Serum Albumin (BSA) as standard: a micro concentration (from $10 \mathrm{mg} / \mathrm{L}$ to $100 \mathrm{mg} / \mathrm{L}$ ) and a macro concentration (from $120 \mathrm{mg} / \mathrm{L}$ to $250 \mathrm{mg} / \mathrm{L}$ ). The absorbance was measured at $760 \mathrm{~nm}$ and the protein analysis was performed in replicates (6) for the sixth day of fermentation. The maximum specific growth rate $\left(\mu_{\text {max }}\right)$ was calculated by determining the slope of the linear regression obtained from a growth curve relating biomass density $(\mathrm{X})$ to fermentation time $(\mathrm{t})$ during the exponential phase. The doubling time (Dt) was calculated according to the equation previously described by Guillard (Guillard, 1973). 


\section{Results}

\subsection{Biomass, chlorophyll and total protein production on the preliminary fermentations}

In terms of cell growth, all formulations (from Condition 2 to Condition 4) from preliminary fermentations in comparison with the control (Condition 1) resulted in better performance (Figure 1a). However, the highest biomass density $(0.40 \mathrm{~g} / \mathrm{L})$ occurred when $S$. platensis culture was supplemented with GLC and FBS simultaneously (Condition 4). The literature demonstrated that supplementation of S. platensis cultures with GLC increased their biomass productivity (Muliterno et al., 2005; Chen et al., 1997). Furthermore, it is also known the strong contributions FBS represents for the animal cell culture technology. This way, a synergistic rule and increases of S. platensis biomass was also expected. Concerning the chlorophyll production, only a-chlorophyll was measured according to equation described by Mohsenpour et al. (2012). The pigment was measured on the first $(\mathrm{t}=0)$ and last day $(\mathrm{t}=10)$ of the photo-fermentation and as it was expected the condition with higher biomass density presented the highest value of chlorophyll content $\left(0.63 \mathrm{mg} / \mathrm{m}^{3}\right)$. The culture medium supplemented only with GLC (Condition 2) or FBS (Condition 3) resulted in similar values of maximum biomass density $(0.24 \mathrm{~g} / \mathrm{L})$ and a-chlorophyll content $\left(0.45 \mathrm{mg} / \mathrm{m}^{3}\right)$. In opposite of biomass production, the highest total protein content $(102.7 \mathrm{mg} / \mathrm{L})$ was verified using only FBS as supplement (Figure $1 \mathrm{~b})$.

Figure 1. Preliminary photo-fermentations, (a) biomass density behavior and (b) total protein content for different culture conditions. Condition 1: S. platensis cultivated in Guillard's W.C medium; Condition 2: S. platensis cultivated in Guillard's W.C medium supplemented with GLC (5.25 g/L); Condition 3: S. platensis cultivated in Guillard's W.C medium supplemented with FBS (2.75\%) and Condition 4: S. platensis cultivated in Guillard's W.C medium supplemented with GLC and FBS. Biomass density was obtained from average \pm standard deviation of 2 samples. The data from the total protein content was verified in replicates (6). The protein analysis was performed in the 6th day of photo-fermentations. The averages of standard deviations were Condition 1 of \pm 5.62 ; Condition 2 of \pm 7.11 ; Condition 3 of \pm 9.65 and Condition 4 of \pm 2.69 ).

(a)

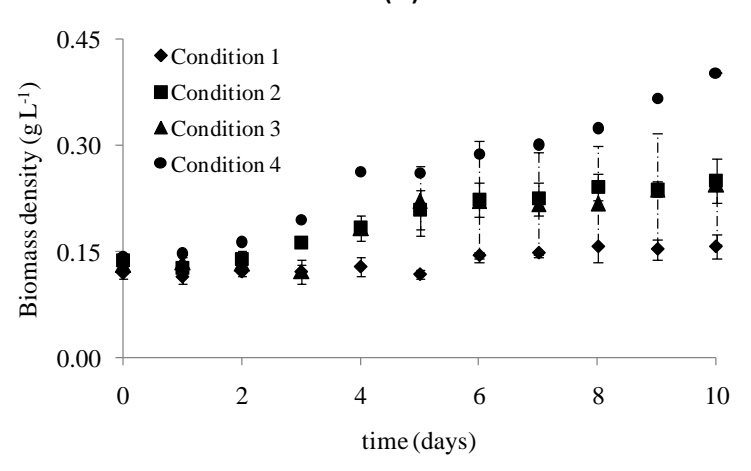

(b)

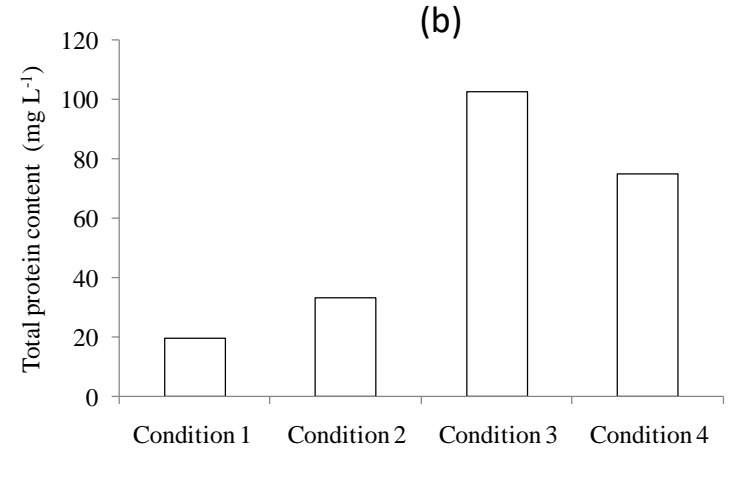

Source: Authors.

It seems that even the combination of GLC and FBS improve the microalgal growth, the protein production does not follow the same rule. The effect of FBS as a single supplement (Condition 3) showed better results than its association with GLC (Condition 4). Besides, the values of $\mu_{\max }$ and Dt demonstrated from Condition $2\left(0.128 \mathrm{~d}^{-1} ; 5.4 \mathrm{~d}\right)$ to Condition $4\left(0.119 \mathrm{~d}^{-}\right.$ $\left.{ }^{1} ; 5.9 \mathrm{~d}\right)$ increased in the $\mathrm{S}$. platensis growth rate when compared with the control $\left(0.046 \mathrm{~d}^{-1} ; 15 \mathrm{~d}\right)$. However, $\mu_{\max }$ was higher when supplemented only with FBS $\left(0.297 \mathrm{~d}^{-1} ; 2.3 \mathrm{~d}\right)$, which consequently leads to a lower value of Dt.

\subsection{Factorial experiment design - biomass and protein analysis}

As expected, all trials (Table 1) presented better performance than control (Condition 16). However, contrasting 
information was observed in the factorial design. As it is displayed in Table 1, the highest value for biomass (Condition $15-$ $0.44 \mathrm{~g} / \mathrm{L}$ ) did not show the highest total protein content. Instead of that, another assay with higher biomass density (Condition $12-0.43 \mathrm{~g} / \mathrm{L})$ presented the biggest protein content $(166.3 \mathrm{mg} / \mathrm{L})$. The main difference between these assays was the amount of GLC used during the cultivation. It suggested the GLC concentration is essential to the production of proteins by S. platensis.

The experimental results were fitted using a multiple regression model with the Statistica®7.0 software. A statistical evaluation of the parameter estimation was performed using the Student's t-test. The parameters with a significance level below $10 \%(\mathrm{p}<0.10)$ were considered significant. The determination coefficient $\mathrm{R}^{2}$ was 0.908 for the total protein content and 0.823 for the biomass density, indicating that the two regression equations were shown in Eqs. (1) and (2) fit well with the experimental data. The measured experimental data had values that were similar to those provided by the empirical equation. The residuals were randomly distributed around zero, showing no trends in the distribution.

Table 1. Effect coding for the complete star-expanded $2^{2}$ factorial design.

\begin{tabular}{|c|c|c|c|c|c|}
\hline \multirow{2}{*}{ Variable } & \multicolumn{5}{|c|}{ Level } \\
\cline { 2 - 6 } & $\boldsymbol{- \alpha ( - 1 . 4 1 )}$ & -1 & $\boldsymbol{0}$ & $\boldsymbol{1}$ & $+\boldsymbol{\alpha}(+1.41)$ \\
\hline$F B S(\% v / v)$ & 0.42 & 0.50 & 2.75 & 5.00 & 5.89 \\
\hline$G L C(g / L)$ & 1.44 & 0.50 & 5.25 & 10.00 & 11.94 \\
\hline
\end{tabular}

Source: Authors.

Total protein content $=156.749+17.004 \mathrm{X} 1-15.042 \mathrm{X} 1^{2}+8.720 \mathrm{X} 2-6.079 \mathrm{X} 2^{2}+9.383 \mathrm{X} 1 \mathrm{X} 2$ (Eq. 1)

Biomass density $=0.436+0.021 \mathrm{X} 1-0.03 \mathrm{X} 1^{2}+0.008 \mathrm{X} 2-0.011 \mathrm{X} 2^{2}-0.014 \mathrm{X} 1 \mathrm{X} 2$

(Eq. 2)

By building the boundary curves (Maple ${ }^{8} 8$ software), the influence of GLC concentration and FBS on the biomass density could be considered (Figure 2). As also shown in Figure 2, the optimized region for the biomass density corresponded with lower total protein content. For the central point experiments $(13,14$, and 15$)$ with a $5.25 \mathrm{~g} / \mathrm{L} \mathrm{GLC}$ and a $2.75 \%$ v/v FBS, intermediate values for the average biomass density and the total protein content were obtained as given in Table 2 and observed in Figure 2. The central point was located near the beginning of the region that maximizes the biomass density and at these conditions; the total protein values are higher than $130 \mathrm{mg} / \mathrm{L}$.

The values of $\mu_{\max }$ and $\mathrm{Dt}$ for the twelve conditions confirmed that assay 10 obtained high value to the maximum specific growth rate $\left(0.52 \mathrm{~d}^{-1}\right)$. Consequently, the lowest $\mathrm{Dt}(1.34 \mathrm{~d})$. As the preliminary photo-fermentation, all formulations also increased the S. platensis growth rate when compared with the control. In relation to chlorophyll content, it was observed that assays with similar biomass density, such as assays 9,10 , and 14 presented contents of $0.69,0.63$, and $0.64 \mathrm{mg} / \mathrm{m}^{3}$ (data not shown), respectively. 
Figure 2. Two-dimensional plots for the total protein content (solid lines) and the biomass density (dashed lines) as a function of a FBS (\% v/v) and GLC (g/L).

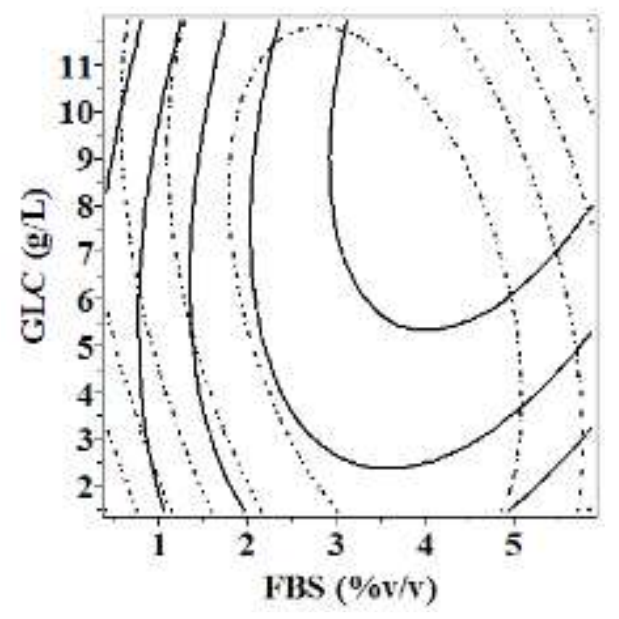

Source: Authors.

\subsection{Cost performance}

As discussed by Slade and Bauen (2013), cost analysis is an interesting tool used to identify the process elements helping focus research. Here, the economic viability of the total protein content from Spirulina platensis cultures using supplemented medium (FBS and GLC) was carried out using the discounted criteria. However, it was included only the cultivation (photo-fermentation) and harvesting process step.

The main types of equipment proposed to the processes were basically composed of a stainless steel mixing tank to the culture medium storage, a tubular photo-bioreactor operating at batch mode, besides positive displacement pumps, filters for large particles separating from the medium, and a solid-liquid medium separation centrifuge. All equipment and their prices are shown in Table 2 . The photo-bioreactor has an operating cycle of $168 \mathrm{~h}$ with a total volume of $120 \mathrm{~L}$; and considering that the plant operating time was of 330 days/year, around 5,657.14L of culture medium should be used per year.

The plant operating cost is the sum of all expenses related to raw material, labor, utilities, etc. Besides, the current work has a technological infrastructure branch. To calculate the capital investment were proposed averages of the multiplier total cost purchase (CP) for each cost item referent to plant as shown in Table 3. Detailed definitions of the various cost items can be found in the technical literature (Petrides, 2020). Furthermore, the cost of raw materials is presented in Table 4. The values were based on manufacturer catalogs and are considered a gain range of 50\%. It is important to note the price was given in function of $1 \mathrm{~L}$ or $1 \mathrm{Kg}$.

Considering that annually $5,657.14 \mathrm{~L}$ of medium culture was used in the process, the plant capacity was estimated from the total protein content $(0.166 \mathrm{~g} / \mathrm{L})$. As mentioned before, this estimative refers only to the step of the culture system and it was not included the step of the target-product downstream. By the calculus using raw materials, it was possible to estimate the total cost of the production. The selling price to the total protein from Spirulina was US\$ 1,649.5/g, as pharmaceutical standard priced. Since the analysis was performed only for cell cultivation and fermentative process step, it was considered the cost of growing algae for obtaining protein, around 50\% of the total value. Table 4 shows a summary of the economic analysis performed. An interest rate per year of 5\% was used and DPBP (Turton, 2012) was almost 3.3 years. The value can be considered compatible with the minimum value standard expected for this type of process. 
Table 2. Star-expanded $2^{2}$ factorial design for supplement screening. S. platensis was inoculated in different media at $0.1 \mathrm{~g} / \mathrm{L}$ and cultivated at $25^{\circ} \mathrm{C}$. Control: $S$ platensis cultivated in WC medium.

\begin{tabular}{|c|c|c|c|c|}
\hline \multirow{2}{*}{ Condition } & \multicolumn{2}{|c|}{ Independent variable } & \multicolumn{2}{|c|}{ Dependent variable } \\
\hline & $\operatorname{FBS}(\% \mathrm{v} / \mathrm{v})$ & GLC $(g / L)$ & Biomass density(g/L) & Total protein content $(\mathrm{mg} / \mathrm{L})$ \\
\hline 5 & $0.50(-1)$ & $0.50(-1)$ & 0.32 & 115.5 \\
\hline 6 & $5.00(+1)$ & $0.50(-1)$ & 0.41 & 127.0 \\
\hline 7 & $0.50(-1)$ & $10.00(+1)$ & 0.38 & 111.2 \\
\hline 8 & $5.00(+1)$ & $10.00(+1)$ & 0.41 & 160.2 \\
\hline 9 & $0.42(-\alpha)$ & $5.25(0)$ & 0.37 & 107.4 \\
\hline 10 & $5.89(+\alpha)$ & $5.25(0)$ & 0.41 & 160.6 \\
\hline 11 & $2.75(0)$ & $1.44(-\alpha)$ & 0.42 & 137.4 \\
\hline 12 & $2.75(0)$ & $11.94(+\alpha)$ & 0,43 & 166.3 \\
\hline 13 & $2.75(0)$ & $5.25(0)$ & 0.43 & 156.8 \\
\hline 14 & $2.75(0)$ & $5.25(0)$ & 0.44 & 156.7 \\
\hline 15 & $2.75(0)$ & $5.25(0)$ & 0.44 & 156.6 \\
\hline 16 (Control) & - & - & 0.13 & 19.4 \\
\hline
\end{tabular}

Source: Authors.

Table 3. Indexes of the total investment composition from the equipment cost.

\begin{tabular}{|c|c|c|}
\hline Item cost & Average multiplier & Investment (US\$) \\
\hline \multicolumn{3}{|c|}{ 1. Direct plant cost $(\mathrm{DC})$} \\
\hline Installation & $0.50 \times \mathrm{XP}$ & $52,390.494$ \\
\hline Tubing & $0.40 \times \mathrm{CP}$ & $41,912.395$ \\
\hline Instrumentation & $0.35 \mathrm{X} \mathrm{CP}$ & $36,673.346$ \\
\hline Isolation & $0.03 \mathrm{X} \mathrm{CP}$ & $3,143.430$ \\
\hline Electrical installation & $0.15 \mathrm{X} \mathrm{CP}$ & $15,717.148$ \\
\hline Subtotal & \multicolumn{2}{|c|}{$149,836.814$} \\
\hline \multicolumn{3}{|c|}{ 2. Indirect plant cost $(\mathrm{CI})$} \\
\hline Engineering & $0.25 \mathrm{X} \mathrm{CP}$ & $26,195.247$ \\
\hline Construction & $0.35 \mathrm{X} \mathrm{CP}$ & $36,673.346$ \\
\hline Subtotal & \multicolumn{2}{|c|}{$62,868.593$} \\
\hline \multicolumn{3}{|c|}{ 3. Total plant cost $(T P C=D C+C I)$} \\
\hline Contractor's Fees (CF) & $0.05 \mathrm{X} \mathrm{CP}$ & $5,239.049$ \\
\hline Contingency $(\mathrm{C})$ & $0.10 \mathrm{X} \mathrm{CP}$ & $10,478.099$ \\
\hline \multicolumn{3}{|c|}{ 4. Direct fixed capital $(\mathrm{DFC}=\mathrm{TPC}+\mathrm{CF}+\mathrm{C})$} \\
\hline Working capital (WC) & $0.10 \mathrm{X} \mathrm{CP}$ & $10,478.099$ \\
\hline Starting cost (SC) & $0.05 \mathrm{X} \mathrm{CP}$ & $5,239.049$ \\
\hline \multicolumn{3}{|c|}{ 5. Investment capital $(I C=D F C+W C+S C)$} \\
\hline Total & \multicolumn{2}{|c|}{$244,139.70$} \\
\hline
\end{tabular}




\section{Discussion}

Supplementation of culture media for cyanobacteria to increase their biomass and/or added value to their other components, such as lipids and proteins, is constantly being studied. As reported by Michalak and Chojnacka (2015), Spirulina is the most known source of single-cell protein and has nutraceutical valuable properties.

It is known that there are at least two independent metabolic processes, photosynthetic metabolism, and aerobic respiration in the mixotrophic growth of Spirulina sp (Chojnacka and Noworyta, 2004). In the current work, mixotrophic conditions (adding GLC and / or FBS) provide increments in the biomass density and also the total protein content. It suggested this kind of carbon source can contribute to the production of algal extracts which might be used in the products for plants, animals, human (cosmetics), and technological inputs.

Interesting findings were presented by Chang et al. (2013), who observed the addition of organic carbon stimulate the microalgae (Spirulina) growth. Also, the mixotrophic grown biomass showed an increase in the content of protein, which could be converted into biofuel. Muliterno et al. (2005) using a fed batch mode demonstrated the GLC supplementation in the Zarrouk medium, as an organic carbon source, increased the biomass productivity. However, these researchers also observed that sugar needs to be used in low concentration $(0.5 \mathrm{~g} / \mathrm{L})$. Chen and Zhang (1997) verified the use of GLC in a batch culture system can increase the phycocyanin production in S. platensis.

Several studies have been found demonstrating possible improvements in the growth of S. platensis with supplemented medium, using whey cheese, glucose, organic fertilizers (Ak et al., 2012; Muliterno et al., 2005), or as in the current work, fetal bovine serum. FBS is the most widely used growth supplement for cell culture media because of its high content of growth-promoting factors. In general, FBS delivers nutrients, growth, and attachment factors and protects cells from oxidative damage and apoptosis. As Gstraunthaler, 2020), FBS contains glucose (from 0.85 to $1.81 \mathrm{mg} / \mathrm{mL}$ ), protein (from 32 to $70 \mathrm{mg} / \mathrm{mL}$ ), creatinin (from 16 to $43 \mu \mathrm{g} / \mathrm{mL}$ ), vitamin A (from 10 to $350 \mathrm{ng} / \mathrm{mL}$ ) and E (1 to $4.2 \mathrm{ng} / \mathrm{mL}$ ), cholesterol (from 120 to $630 \mu \mathrm{g} / \mathrm{mL}$ ), besides blood proteins, hormones, enzymes and salts $\left(\mathrm{Na}^{+}, \mathrm{K}^{+}, \mathrm{Ca}^{2+}, \mathrm{Cl}^{-}\right.$and $\left.\mathrm{Pi}\right)$. Almost all of them can provide the cell growth and embedding in several enzymatic reactions. However, it is also important to note increases in the total number of solute particles in the culture medium modify the osmolality.

Fogg et al. (1973) observed that cyanobacteria preferentially use inorganic nitrogen for growth, particularly nitrates and ammonium but some of them can grow on organic nitrogen (such as creatinin and protein with low molecular weight, aforementioned). Since nitrogen is required for synthesis of the amino acids, which make up proteins, the increase in nitrogen content can result an increase in protein biosynthesis in Spirulina cultures. Besides, the changes in biochemical composition are considered to be an adaptation mechanism to toxicity of osmolality causing the accumulation of the total protein. Finally, the results revealed high values of specific growth $\left(0.46\right.$ and $\left.0.52 \mathrm{~d}^{-1}\right)$ in assays $(6$ and 10) in which FBS was supplemented around $5 \% \mathrm{v} / \mathrm{v}$. It is important to note the high protein content provided by these assays.

The application of novel techniques on the industrial scale would require a significant capital investment and an upscaled version concerning value-products from algal cultivation. There are several studies that simulated the economic feasibility of microalgae production, most of them focusing on biofuel production (Amer et al., 2011; Rios et al., 2013; Richardson et al., 2014). Some authors also evaluated the techno-economic analysis of S. platensis cultivation in a pilot-scale or industrial production and their results differ according to the composition of the algal medium and the type of cultivation used (in raceway ponds or tanks). Serag et al. (2017) analyzed the production of Spirulina in open ponds using Zarrouk medium and a new reduced cost fertilizer based medium developed for biomass production. According to the calculation by Serag et al. (2017), the total cost of this project in Egypt would be US\$240,100 in the first six months, including chemicals, labor, electricity, etc. It is an expensive start-up production; however, it has a quick return in a 2 3 years period with the current market prices. 
Jiménez et al. (2003) evaluated the viability of the industrial production of three strains of S. platensis in raceway ponds using Zarrouk media in Southern Spain. Instead of investigating the cost of this investment, they verified the potential average productivity in a period of 10 months, which resulted in 30 - 32 metric tons of dry powder per hectare per annum. Delrue et al. (2017) evaluated the S. platensis biomass cultivation productivity by comparing the use of three different modified versions of Zarrouk's, Hiri's, and Jourdan's medium and the cultivation in open ponds and photobioreactor. It was observed that modified Zarrouk's medium provided higher biomass productivity than Hiri's and Jourdan's medium, besides that cultivation of Spirulina in pilot-scale tubular photobioreactor also improved biomass productivity during a period of 40day cultivation. However, a techno-economic analysis verified that production cost for photobioreactor is higher (from 18.71 to $75.29 € / \mathrm{kg}$ ) than for open pond cultivation (from 3.86 to $9.59 € / \mathrm{kg}$ ).

The results shown here are for a partially complete system estimated using a culture medium costing model. This model is appropriate to identifying the cost elements of the process that pose the greatest challenge to engineering development. It is likely, however, to underestimate the true cost of microalgae production. This is because a real project would incur costs excluded from this analysis such as the cost of upstream and downstream steps.

Table 4. (A) Estimative of raw materials cost (values according to manufacturers). (B) Overall economic analysis for total protein production from $S$. platensis.

\begin{tabular}{|c|c|c|c|}
\hline \multicolumn{4}{|c|}{ (A) } \\
\hline Compound & Capacity & Unit cost & Total cost (US\$/year) \\
\hline Culture medium & $5,657.14$ L/year & $0.0274(\mathrm{US} \$ / \mathrm{L})$ & 154.738 \\
\hline GLC & $29.678 \mathrm{~kg} /$ year & $0.452(\mathrm{US} \$ / \mathrm{Kg})$ & 13.414 \\
\hline FBS & 332.901 L/year & $5.457(\mathrm{US} \$ / \mathrm{Kg})$ & $1,816.718$ \\
\hline Total & \multicolumn{3}{|c|}{$1,984.87$} \\
\hline \multicolumn{4}{|c|}{ (B) } \\
\hline \multicolumn{3}{|l|}{ Item } & Cost (US\$) \\
\hline \multicolumn{3}{|c|}{ Total investment capital (US\$) } & $244,139.70$ \\
\hline \multicolumn{3}{|c|}{ Total cost of production (US\$/year) } & $1,984.87$ \\
\hline \multicolumn{3}{|c|}{ Plant capacity (g/year) } & $1,016.59$ \\
\hline \multicolumn{3}{|c|}{ Unit production cost (US\$/g) } & 1.95 \\
\hline \multicolumn{3}{|c|}{ Selling price (US\$/g) } & 136.91 \\
\hline \multicolumn{3}{|c|}{ Earnings (US\$/year) } & $139,179.54$ \\
\hline \multicolumn{3}{|c|}{ Gross profit (US\$/year) } & $137,194.67$ \\
\hline \multicolumn{3}{|l|}{ Taxes (US\$/year) } & $54,877.87$ \\
\hline \multicolumn{3}{|c|}{ Net profit (US\$/year) } & $82,316.80$ \\
\hline \multicolumn{3}{|c|}{ Discounted payback period (year) } & 3.29 \\
\hline
\end{tabular}

Source: Authors.

\section{Conclusion}

The findings showed FBS may be an important product to be used as a supplement to cultivated S. platensis. It seems that in the presence of GLC not only biomass density but also the protein content increased during the cultivation. However, it 
is necessary to determine specific concentrations for both supplements in order to obtain a synergetic effect between them. From a practical point of view, these results draw attention to the importance of selecting the source and concentration of carbon and nitrogen in microalgae cultures, because it may modify the metabolic activities and consequently, the composition and nutritional value of microalgae, which is important to consider in nutraceutical production processes. Finally, existing cost estimates should be extended and this will require empirical data on the performance of systems designed specifically for protein production. In future works, a cost analysis using all stages of production, in addition to that which considers the formulation of the culture medium, may be carried out.

\section{Acknowledgments}

The authors gratefully acknowledge the financial supports from the Brazilian agencies CAPES (Coordenação de Aperfeiçoamento de Pessoal de Nível Superior), CNPq (Conselho Nacional de Desenvolvimento Científico e Tecnológico) and FAPEMIG (Fundação de Amparo à Pesquisa do Estado de Minas Gerais).

\section{References}

Ak, I. (2012) Effect of an organic fertilizer on growth of blue-green alga Spirulina platensis. Aquaculture International, 20, 413-422. https://doi.org/10.1007/s10499-011-9473-5

Amer, L., Adhikari, B., \& Pellegrino, J. (2011) Technoeconomic analysis of five microalgae-to-biofuels processes of varying complexity. Bioresource Technology, 102, 9350-9359. 10.1016/j.biortech.2011.08.010

Borowitzka, M. A. (1999) Commercial production of microalgae: ponds, tanks, tubes and fermenters. Journal of Biotechnology, 70, 313-321. https://doi.org/10.1016/S0168-1656(99)00083-8

Chang, Y., Wu, Z., Bian, L., Feng, D., \& Leung, D. Y. C. (2013) Cultivation of Spirulina platensis for biomass production and nutrient removal from synthetic human urine. Applied Energy, 102, 427-431. https://doi.org/10.1016/j.apenergy.2012.07.024

Chen, F., \& Zhang, Y. (1997) High cell density mixotrophic culture of Spirulina platensis on glucose for phycocyanin production using a fedbatch system. Enzyme and Microbial Technology, 20, 221-224. https://doi.org/10.1016/S0141-0229(96)00116-0

Chojnacka, K., \& Noworyta, A. (2004) Evaluation of Spirulina sp. growth in photoautotrophic, heterotrophic and mixotrophic cultures. Enzyme and Microbial Technology, 34, 461-465. https://doi.org/10.1016/j.enzmictec.2003.12.002

Clesceri, L. S., Eaton, A. D., \& Greenberg, A. E. (1998) Standard methods for the examination of water and wastewater, American Public Health Association, 20th ed., Washington D.C.

Coca, M., Barrocal, V., Lucas, S., González-Benito, G., \& García-Cubero, M. (2015) Protein production in Spirulina platensis biomass using beetvinassesupplemented culture media. Food and Bioproducts Processing, 94, 306-312. https://doi.org/10.1016/j.fbp.2014.03.012

Dar, B. A., Khaliq, R., Jha, G. N., Kour, P., \& Qureshi, T. A. (2014) Protective effects of dietary Spirulina against cadmium chloride exposed histoarchitectural changes in the liver of freshwater catfish Clariasbatrachus (Linnaeus, 1758). Indian Journal of Fisheries, 61, 83-87. http://dx.doi.org/10.3126/on.v9i1.5737

Delrue, F., Alaux, E., Moudjaoui, L., Gaignard, C., Fleury, G., Perilhou, A., Richaud, P., Petitjean, M., \& Sassi, J. F. (2017) Optimization of Arthrospira platensis (Spirulina) Growth: From Laboratory Scale to Pilot Scale. Fermentation, 3, 59-73. 10.3390/fermentation3040059

Dillon, J. C., Phuc, A. P., \& Dubacq, J. P. (1995) Nutritional value of the alga Spirulina. World Review of Nutrition and Dietetics. 77, 32-46. DOI: $10.1159 / 000424464$

Fogg, G. E., Stewart, W. D. P., Fay, P., \& Walsby, A. E. (1973) The Blue-Green Algae, Academic Press.

Gstraunthaler, G. (2003) Alternatives to the Use of Fetal Bovine Serum: Serum-free Cell Culture, ALTEX 20, 4/03. http://www.altex.ch/resources/Altex_2003_4_275_281_Gstraunthaler.pdf.

Guillard, R. R. L., \& Lorenzen, C. J. (1972) Yellow-green algae with chlorophyllid-c. Journal of Phycology, 8, 10-14. https://doi.org/10.1111/j.15298817.1972.tb03995.X

Guillard, R. R. L. (1973) Division rates. In. Stein (ed). Handbook of Phycological Methods.V. 1. Cambridge University Press. $289-312$.

Habib, M. A. B., Parvin, M., Huntington, T. C., \& Hasan, M. R. (2008) Review on Culture, Production and Use of Spirulina as Food for Humans and Feeds for Domestic Animals and Fish, FAO Fisheries and Aquaculture Circular, Rome.

Henrikson, R. (2009) Earth food Spirulina, (6a ed.), Ronore Enterprises. 
Hosseini, S. M., Khosravi-Darani, K., \& Mozafari, M. R. (2013) Nutritional and medical applications of Spirulina microalga. Mini Reviews in Medicinal Chemistry, 13, 1231-1237. 10.2174/1389557511313080009

International Serum Industry Association. What is bovine serum used for? http://www.serumindustry.org/documents/Use.pdf .

Jiménez, C., Belén, R. C., Diego, L., \& Niella, F. X. (2003) The Feasibility of Industrial Production of Spirulina (Arthrospira) In Southern Spain. Aquaculture, 217, 179-190. https://doi.org/10.1016/S0044-8486(02)00118-7

Lowry, O. H., Rosebrough, N. J., Farr, A. L., \& Randall, R. J. (1951) Protein measurement with the folin phenol reagent. Journal of Biological Chemistry, $193,265-275$.

Michalak, I., \& Chojnacka, K. (2015) Algae as production systems of bioactive compounds. Engineering in Life Science, 15, 160-176. https://doi.org/10.1002/elsc.201400191

Mohsenpour, S. F, \& Richards, B., Willoughby, N. (2012) Spectral conversion of light for enhanced micro algae growth rates and photosynthetic pigment production. Bioresource Technology, 125, 75- 81. 10.1016/j.biortech.2012.08.072

Muliterno, A., Mosele, P. C., Costa, J. A. V., Hemkemeier, M., Bertolin, T. E., \& Colla, L. M. (2005) Mixotrophic culture of Spirulina platensis microalgae in fed batch. Ciência e Agrotecnologia, 29, 1132-1138. https://doi.org/10.1590/S1413-70542005000600005

Petrides D. Bioprocess design. https://www.cri.or.th/en/mitthai/Announcement\%20and\%20Discussion\%20Pages/BioprocessDesign.pdf.

Rangel-Yagui, C. O., Danesi, E. D. G., Carvalho, J. C. M., \& Sato, S. (2004) Chlorophyll production from Spirulina platensis: cultivation with urea addition by fed-batch process. Bioresource Technology, 92, 133-141. 10.1016/j.biortech.2003.09.002

Richardson, J. W., Myriah, D. J., Xuezhi, Z., Peter, Z., Wei, C., \& Qiang, H. (2014) A financial assessment of two alternative cultivationsystems and their contributions to algae biofuel economic viability. Algal Research, 4, 96-104. https://doi.org/10.1016/j.algal.2013.12.003

Rios, S. D., Torres, C. M., Torras, C., Salvado, J., Mateo-Sanz, J. M., \& Jimenez, L. (2013) Microalgae-based biodiesel: economic analysis of downstream process realistic scenarios. Bioresource Technology, 136, 617-625. https://doi.org/10.1016/j.biortech.2013.03.046

Serag, M. A., Higazy, M. A., Basir, M., Mappiratu, H., Nilawati, J., Rahman, N., \& Bohari, K. C., Burhanuddin, I. (2017) Production Methods, Economics and Effects of Spirulina Food Supplementation on Malnourished Children. International Journal of Scientific and Engineering Research, 8, 1111-1115.

Shelke, A. D., \& Wani, G. P. (2015) Protective effect of dietary supplementation of Spirulina platensis on improvement of growth parameters in mercuric chloride exposed fish, Labeorohita. International Journal of Life Sciences, Special issue A3, 37- 41.

Slade, R., \& Bauen, A. (2013) Micro-algae cultivation for biofuels: Cost, energy balance, environmental impacts and future prospects. Biomass and Bioenergy, 53, 29-38. https://doi.org/10.1016/j.biombioe.2012.12.019

Staines, D., \& Price, P. (2003) Managing serum requirements for cell culture, GIBCO® Cell Culture.

Suali, E., \& Sabartly, R. (2012) Conversion of microalgae to biofuel. Renewable and Sustainable Energy Reviews, 16, 4316-4342. https://doi.org/10.1016/j.rser.2012.03.047

Tortora, G. J. (2007) Microbiology: an introduction, 9th ed., San Francisco: Pearson Benjamin Cummings, The prokaryotes: domains bacteria and archae, $328-9$.

Turton, R. (2012) Analysis, synthesis, and design of chemical processes, (4th ed.), Prentice Hall.

Von Der Weid, D., Dillon, J. C., \& Falquet, J. (2000) Malnutrition: a silent massacre, Antenna Technology. 